\title{
BURANGAITE, A NEW PHOSPHATE MINERAL FROM RWANDA
}

\author{
O. von KNORRING, MARTTI LEHTINEN and TH. G. SAHAMA
}

\begin{abstract}
KNORRING, O. von, LEHTINEN, MARTTI and SAHAMA, Th. G. 1977: Burangaite, a new phosphate mineral from Rwanda. Bull. Geol. Soc. Finland 49: 33-36.

This paper describes a new phosphate, burangaite, from the Buranga pegmatite in Rwanda.

Burangaite is monoclinic with the idealized formula (Na,Ca) $\left(\mathrm{Fe}^{2+}, \mathrm{Mg}\right)_{2} \mathrm{Al}_{10}(\mathrm{OH}, \mathrm{O})_{12}\left(\mathrm{PO}_{4}\right)_{8} \cdot 4 \mathrm{H}_{2} \mathrm{O}, \quad \mathrm{Z}=2$. The crystals exhibit narrow, bladed prisms, elongated parallel to the $b$-axis. Perfect cleavage parallel to 100. Mohs' hardness 5. Streak slightly bluish. Unit-cell data: $a_{0} 25.09 \AA, b_{0} 5.048 \AA, c_{0} 13.45 \AA, \beta 110.91^{\circ}$, space group $C 2 / c$. These parameters and the indexed X-ray powder pattern (Table 1) indicate a marked relationship with dufrenite.

The mineral is blue in color with $\gamma \| b$ and $c \wedge a=11^{\circ}, 2 V_{a}=58^{\circ}$, strong pleochroism, refractive indices $\alpha 1.611, \beta 1.635, \gamma 1.643$. Common hourglass structure with a blue core and a colorless margin.

O. von Knorring, Department of Earth Sciences, Leeds University, Leeds LS2 9JT, England.

Martti Lehtinen and Th. G. Sahama, Department of Geology and Mineralogy, University of Helsinki, P.O. Box 115, SF-00170 Helsinki 17, Finland.
\end{abstract}

\section{Introduction}

The occurrence of a long-prismatic bluish phosphate mineral from the Buranga pegmatite, Rwanda, was noted and provisionally described by one of us (von Knorring 1973). This mineral appears to be confined to corroded aggregates of bertossaite (von Knorring and Mrose 1966), trolleite, scorzalite (identified chemically and by X-ray powder pattern) and quartz. It forms either a replacement product of scorzalite which it closely resembles, or conspicuous bluish-green radiating crystals, with distinct dichroism, set in white, fibrous late-stage apatite, and it is commonly associated with bjarebyite (von Knorring and Fransolet 1975), wardite and other phosphates under study. Wardite occurs as white crystals of pyramidal habit, up to $2 \mathrm{~mm}$ in size, with dominating $\{012\}$ and $\{013\}$, narrow $\{011\}$ and with small $\{001\}$ and $\{110\}$. Its $\mathrm{X}$-ray powder pattern matches that published by Lindberg (1957).

At an early stage of the investigation, it was observed that the unknown bluish phosphate mineral resembled souzalite from the Corrego Frio pegmatite in Brazil, described by Pecora and Fahey (1949), but no similarity was found between the powder patterns of the two minerals. The Buranga mineral 

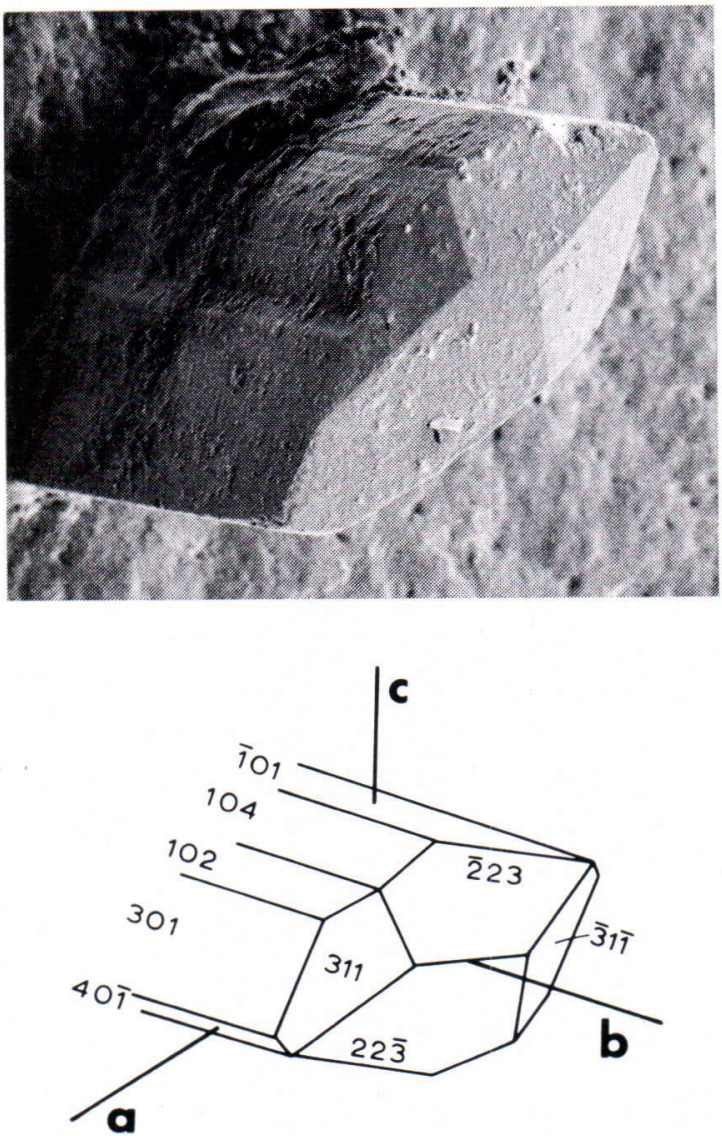

Fig. 1. Crystal habit of burangaite from the Buranga pegmatite, Rwanda. A. Scanning electron micrograph. x 200. B. Idealized crystal form.

represents a new phosphate species here named burangaite according to the locality. The properties of this mineral are presented in this paper. The name has been approved by the Commission on New Minerals and Mineral Names of the International Mineralogical Association.

\section{Crystal morphology}

The long prismatic crystals of burangaite are characteristically bladed in appearance, with crystallographic $b$ as the prism axis. The habit is illustrated in Fig. 1 A. The faces of this crystal were smooth enough to allow identification. Fig. 1 B reproduces the idealized crystal form with the assigned indices. The mineral exhibits a perfect cleavage parallel to 100 .

\section{Crystal geometry}

Burangaite is monoclinic. Its X-ray powder pattern is reproduced in Table 1 . The calculated indexing of the powder lines was checked on the basis of the series of $b$ - and $c$-axis $\mathrm{X}$-ray precession photographs. The powder pattern of burangaite resembles markedly that of dufrenite as presented by Moore (1970). The systematic extinctions found in the X-ray single-crystal photographs agree with the space group $\mathrm{C} 2 / \mathrm{c}$. The powder data of Table 1 were used for least-squares refinement of the cell parameters. Table 2 summarizes the unit-cell data for burangaite, dufrenite and souzalite. With respect to the cell data, burangaite is related to dufrenite rather than to souzalite.

\section{Chemistry}

The material subjected to wet chemical analysis $(200 \mathrm{mg}$ ) was picked by hand under a binocular microscope and is considered pure. The result of the analysis is summarized in Table 3 which gives also the unit-cell content calculated on the basis of the cell volume and density. In addition, the table indicates the composition of the associated scorzalite. When the idealized formula derived from the chemical composition of burangaite is compared with Moore's (1970) of souzalite and Cornish dufrenite, the following relationship are noted:

burangaite: $\quad(\mathrm{Na}, \mathrm{Ca})_{2}(\mathrm{Fe}, \mathrm{Mg})_{2} \mathrm{Al}_{10}(\mathrm{OH}, \mathrm{O})_{12}\left(\mathrm{PO}_{4}\right)_{8}$. $4 \mathrm{H}_{2} \mathrm{O}$, with $\mathrm{Z}=2$, 
Table 1. X-ray powder pattern of burangaite. Philips wide angle goniometer, nickel filtered copper radiation, internal corundum standard.

\begin{tabular}{|c|c|c|c|c|c|c|c|c|c|c|}
\hline $\mathrm{h}$ & $\mathrm{k} 1$ & ${ }_{(\mathrm{me}}^{\mathrm{d}}$ & & $\begin{array}{c}\mathrm{d} \\
\text { (calc.) }\end{array}$ & I & h k 1 & $\underset{(m e}{d}$ & & $\begin{array}{c}\mathrm{d} \\
\text { (calc.) }\end{array}$ & I \\
\hline 2 & 00 & 11.71 & $\mathrm{x}$ & 11.72 & 100 & $\left.\begin{array}{lll}10 & 0 & 0\end{array}\right)$ & & & (2.344 & \\
\hline-2 & 02 & 6.61 & $\mathrm{x}$ & 6.60 & 20 & $\begin{array}{lll}0 & 2 & 2\end{array}$ & & & 2.342 & \\
\hline 0 & 02 & 6.28 & & 6.28 & 5 & -515 & 2.339 & $\mathrm{~b}$ & 2.340 & 12 \\
\hline 4 & 00 & 5.86 & $\mathrm{x}$ & 5.86 & 11 & -421 J & & & 2.339 & \\
\hline 1 & 10 & 4.94 & $\mathrm{x}$ & 4.93 & 18 & $-10 \quad 0 \quad 4)$ & & & $\{2.316$ & \\
\hline 2 & 02 & 4.86 & $\mathrm{x}$ & 4.86 & 41 & $\left.\begin{array}{lll}9 & 1 & 0\end{array}\right\}$ & 2.314 & & $\left\{\begin{array}{l}2.314 \\
\text { S }\end{array}\right.$ & 3 \\
\hline-3 & 11 & 4.281 & $\mathrm{x}$ & 4.276 & 8 & -4061 & & & 2.241 & \\
\hline-1 & $12\}$ & & & $\{4.030$ & 30 & $222\}$ & 2.239 & b & $\left\{\begin{array}{l}2.240 \\
\text {. }\end{array}\right.$ & 4 \\
\hline-6 & $\left.\begin{array}{ll}0 & 2\end{array}\right\}$ & 4.026 & & 4.023 & 30 & 115 & 2.174 & & 2.169 & 3 \\
\hline 6 & 00 & 3.904 & $\mathrm{x}$ & 3.906 & 10 & $\left.\begin{array}{lll}0 & 0 & 6\end{array}\right)$ & & & 2.094 & \\
\hline 3 & 11 & 3.801 & $\mathrm{x}$ & 3.800 & 11 & $-806\}$ & 2.091 & $\mathrm{~b}$ & 2.093 & 6 \\
\hline 4 & 02 & 3.682 & $\mathrm{x}$ & 3.679 & 3 & $-12 \quad 0 \quad 2$ & & & 2.088 & \\
\hline-5 & 11 & 3.559 & $\mathrm{x}$ & 3.559 & 10 & $\begin{array}{l}42 \\
4\end{array}$ & & & $\int 2.081$ & \\
\hline 5 & $\begin{array}{ll}1 & 0\end{array}$ & 3.436 & & 3.435 & 2 & $-1112\}$ & 2.079 & & $\left\{\begin{array}{l}2.078 \\
2.078\end{array}\right.$ & 3 \\
\hline-1 & $13)$ & & & $\{3.318$ & & -915 & & & 2.058 & \\
\hline-3 & $13\}$ & 3.318 & $\mathrm{x}$ & 3.318 & 39 & $\begin{array}{lll}7 & 1 & 3\end{array}$ & 2.058 & & 2.057 & 9 \\
\hline 0 & 04 & 3.141 & $\mathrm{x}$ & 3.140 & 25 & $\left.\begin{array}{lll}-11 & 1 & 3\end{array}\right)$ & & & 2.056 & \\
\hline-8 & $\begin{array}{ll}0 & 2\end{array}$ & 3.115 & & $\{3.115$ & & -1111 & 2.044 & $\mathrm{x}$ & 2.045 & 32 \\
\hline 5 & $11\}$ & 3.115 & & 3.113 & 70 & -224 & 2.016 & & 2.015 & 10 \\
\hline 1 & 134 & 3.081 & $\mathrm{x}$ & 3.081 & 90 & $\begin{array}{lll}12 & 0 & 0\end{array}$ & 1.9537 & $\mathrm{x}$ & 1.9531 & 10 \\
\hline-5 & $13\}$ & 0.001 & $\mathbf{x}$ & 3.080 & 90 & $\left.\begin{array}{lll}2 & 0 & 6\end{array}\right)$ & 1.9434 & & $\{1.9443$ & \\
\hline 8 & 00 & 2.928 & $\mathrm{x}$ & 2.930 & 12 & $-1006\}$ & 1.9434 & & 1.9436 & 15 \\
\hline-7 & 11 & 2.913 & $\mathrm{x}$ & 2.913 & 26 & 820 & 1.9136 & & 1.9122 & 6 \\
\hline 6 & 02 & 2.884 & & 2.887 & 11 & 622 & 1.9001 & $\mathrm{x}$ & 1.9002 & 6 \\
\hline-3 & 14 & & & ( 2.796 & & 804 & 1.8402 & & 1.8396 & 4 \\
\hline 2 & 04 & 2.794 & $\mathrm{x}$ & 2.794 & 22 & -517 & 1.7934 & & 1.7948 & 2 \\
\hline 7 & 10 & & & 2.790 & & & 1.7624 & & & 2 \\
\hline-8 & 04 & 2.670 & & 2.670 & 2 & & 1.7199 & & & 3 \\
\hline 7 & $\left.\begin{array}{ll}1 & 1\end{array}\right)$ & & & $\int 2.567$ & & & 1.6966 & & & 10 \\
\hline 1 & $\left.\begin{array}{ll}1 & 4\end{array}\right\}$ & 2.568 & & 2.564 & 20 & & 1.6746 & & & 28 \\
\hline 0 & 20 & 2.524 & $\mathrm{x}$ & 2.524 & 8 & & 1.6587 & & & 2 \\
\hline-10 & 02 & 2.509 & & 2.509 & 2 & & 1.6401 & & & 2 \\
\hline-9 & 11 & 2.417 & $\mathrm{x}$ & 2.417 & 5 & & 1.6101 & & & 7 \\
\hline 2 & 21 & 2.388 & & 2.387 & 4 & & 1.5580 & & & 10 \\
\hline-3 & 15 & & & ( 2.372 & & & 1.5403 & & & 12 \\
\hline 5 & 13 & 2.371 & & 2.369 & 5 & & 1.5147 & & & 2 \\
\hline-9 & 13 & & & 2.368 & & & 1.4578 & & & 3 \\
\hline 8 & 02 & 2.353 & $\mathrm{x}$ & 2.353 & 13 & & 1.4435 & & & 2 \\
\hline
\end{tabular}

$\mathrm{b}=$ broad line. $\quad \mathrm{x}=$ used for calculating the unit-cell parameters.

dufrenite: $\mathrm{Ca} \cdot{ }_{5} \mathrm{Fe}_{12}(\mathrm{OH})_{12}\left(\mathrm{PO}_{4}\right)_{8} \cdot 4 \mathrm{H}_{2} \mathrm{O}, \quad \mathrm{Z}=2$ Table 2. Unit-cell data for burangaite, dufrenite souzalite: $(\mathrm{Mg}, \mathrm{Fe})_{6}(\mathrm{Al}, \mathrm{Fe})_{8}(\mathrm{OH})_{12}\left(\mathrm{PO}_{4}\right)_{8}$. and souzalite. Uncertainty of the last decimal in $4 \mathrm{H}_{2} \mathrm{O}$,

$$
\mathrm{Z}=1
$$

\section{Optical and physical properties}

Burangaite. Dufrenite. Souzalite. This paper. Moore Moore (1970). (1970).

The optical orientation of burangaite is $\gamma$ $\| b, c \wedge \alpha=11^{\circ}$ in the acute angle $\beta$. Strong parentheses.

pleochroism with $\alpha$ light blue, $\beta$ dark blue,

\begin{tabular}{llclclc}
\hline & & & & \\
$\mathrm{a}_{0}$ & $(\AA)$ & 25.09 & $(1)$ & 25.84 & $(2)$ & 12.58 \\
$\mathrm{~b}_{0}$ & $(\AA)$ & 5.048 & $(3)$ & 5.126 & $(3)$ & 5.10 \\
$\mathrm{c}_{0}$ & $(\AA)$ & 13.45 & $(1)$ & 13.78 & $(1)$ & 13.48 \\
$\beta$ & \multicolumn{7}{c}{$110.91^{\circ}$} & $(8)$ & $111.20^{\circ}$ & $(6)$ & $113.0^{\circ}$ \\
Space group & $\mathrm{C} 2 / \mathrm{c}$ & $\mathrm{C} 2 / \mathrm{c}$ & $\mathrm{A} 2 / \mathrm{m}$ or $\mathrm{A} 2$ \\
\hline
\end{tabular}


Table 3. Chemical composition of burangaite and associated scorzalite. Analyst. O. von Knorring.

\begin{tabular}{lrlrc}
\hline & $\begin{array}{c}\text { Burangaite. } \\
\text { Wt. } \%\end{array}$ & $\begin{array}{c}\text { Burangaite. } \\
\text { Unit-cell } \\
\text { content. }\end{array}$ & $\begin{array}{c}\text { Scorzalite. } \\
\text { Wt. } \%\end{array}$ \\
\hline $\mathrm{Al}_{2} \mathrm{O}_{3}$ & 34.35 & $\mathrm{Al}$ & 20.05 & 30.25 \\
$\mathrm{Fe}_{2} \mathrm{O}_{3}$ & 1.14 & $\mathrm{Fe}^{3+}$ & 0.43 & - \\
$\mathrm{FeO}$ & 6.26 & $\mathrm{Fe}^{2+}$ & 2.59 & 16.37 \\
$\mathrm{MnO}$ & 0.40 & $\mathrm{Mn}$ & 0.17 & 0.85 \\
$\mathrm{MgO}$ & 2.00 & $\mathrm{Mg}$ & 1.48 & 2.90 \\
$\mathrm{CaO}$ & 1.88 & $\mathrm{Ca}$ & 1.00 & 0.80 \\
$\mathrm{Na} \mathrm{N}_{2} \mathrm{O}$ & 2.93 & $\mathrm{Na}$ & 2.81 & - \\
$\mathrm{P}_{2} \mathrm{O}_{5}$ & 37.65 & $\mathrm{P}$ & 15.79 & 41.96 \\
$\mathrm{H}_{2} \mathrm{O}+$ & 11.60 & $\mathrm{H}$ & 38.33 & 5.60 \\
Insoluble & 2.06 & $\mathrm{O}$ & 96.00 & 1.41 \\
Totals & 100.27 & & & 100.14 \\
\hline Densityt $\dagger$ & 3.05 & & & 3.30
\end{tabular}

$\dagger$ By suspension in Clerici solution. $\gamma$ colorless, absorption $\beta>\alpha>\gamma \cdot 2 V_{\alpha}=58^{\circ}$ (calculated $60^{\circ}$ ) with dispersion $r>v$. Refractive indices: $\alpha=1.611 \pm 0.002, \beta=1.635 \pm$ $0.002, \gamma=1.643 \pm 0.001$. Crystals often show an hourglass structure with a blue core and colorless margin. A microprobe test indicated slightly higher Fe and Mn contents in the core than in the margin. Streak weakly bluish. Mohs' hardness 5 .

\section{References}

Knorring, O. von and Mrose, M. E. (1966) Bertossaite, $\quad(\mathrm{Li}, \mathrm{Na})_{2}(\mathrm{Ca}, \mathrm{Fe}, \mathrm{Mn}) \mathrm{Al}_{4}\left(\mathrm{PO}_{4}\right)_{4}(\mathrm{OH}, \mathrm{F})_{4}$, a new mineral from Rwanda (Africa). Can. Mineral. 8: 668.

Knorring, O. von (1973) Notes on pegmatite minerals from Rwanda, Uganda and South West Africa. 17th Ann. Rep. Res. Inst. African Geol., Univ. Leeds, 72-73.

Knorring, O. von and Fransolet, A. M. (1975) An occurrence of bjarebyite in the Buranga pegmatite, Rwanda. Schweiz. Min. Petr. Mitt. 55: $9-18$.
Lindberg, M. L. (1957) Relationship of the minerals avelinoite, cyrilovite and wardite. Am. Mineral. 42: 204-213.

Moore, P. B. (1970) Crystal chemistry of the basic iron phosphates. Am. Mineral. 55: 135-169. Pecora, W. T. and Fahey, J. J. (1949) The Corrego Frio pegmatite, Minas Gerais: Scorzalite and souzalite, two new phosphate minerals. Am. Mineral. 34: 83-93.

Manuscript received, April 20, 1976. 